\title{
Race and Racism: Some Salient Issues
}

\author{
Vijay Naidu
}

\section{Contents}

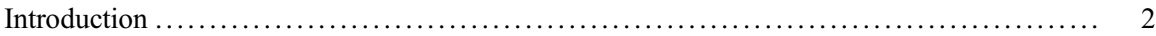

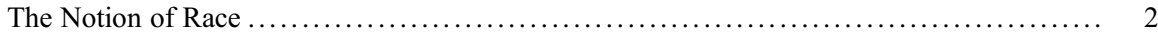

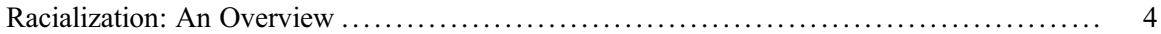

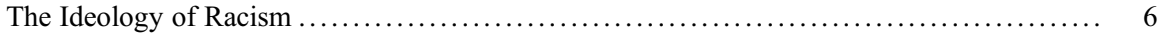

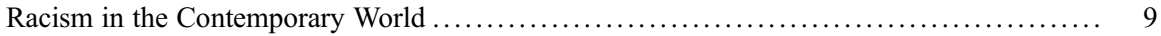

"Old" and "New" Racism ................................................... 9

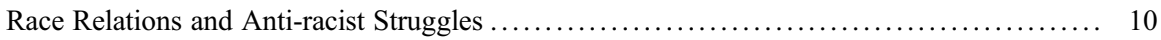

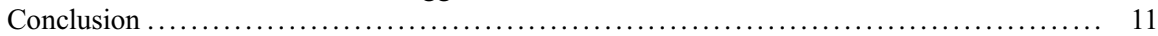

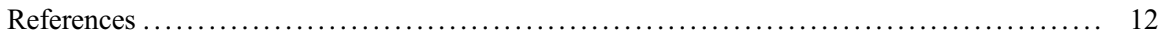

\begin{abstract}
It can be said that virtually all member states of the United Nations are multiethnic, and yet racism and ethnic discrimination remain significant features of many of these countries. This chapter examines the notions of race and ethnicity, the origins of racialization and racism, as well as ethnic discrimination. It alludes to the historical significance of the enslavement of millions of Africans to labor in the plantations and mines of the Americas and Caribbean islands, colonialism in Africa, Asia, and the Pacific, and international labor migration to contemporary forms of racism and interethnic relations. The violent displacement and movement of thousands of refugees and asylum seekers from Iraq, Afghanistan, and Syria to Western countries have given rise to xenophobia, Islamophobia, and racism in the latter states. Interethnic tensions and conflicts remain legacies of an earlier epoch of uneven and unequal development as well as discriminatory practices in most postcolonial states. The struggle against racism and ethnic discrimination is an ongoing process.
\end{abstract}

V. Naidu ( $\square$ )

University of the South Pacific, Suva, Fiji

e-mail: vijaynaidu61@gmail.com; vijay.naidu@usp.ac.fj

(C) The Author(s), under exclusive licence to Springer Nature Singapore Pte Ltd. 2019 


\section{Keywords \\ Race $\cdot$ Racism $\cdot$ Ethnicity $\cdot$ Colonialism $\cdot$ Anti-racist struggles}

\section{Introduction}

In the early twenty-first century, notions of race and racism are widely used and their manifestation can be seen in everyday life at global, national, and local levels. Most recently, the terrorist attack on worshippers that resulted in 50 deaths and 50 injured and hospitalized in Christchurch, New Zealand, show that a relatively remote and apparently peaceful country is not spared the extreme violence of a white supremacist. International main stream media and social media cover matters relating to race, ethnicity, and racism on a routine, if differential basis. Prominent among these are statements and actions of President Donald Trump and the reassertion of white supremacist views and activities by American and European right wing and neo-Nazi groups; the "Black Lives matter movement"; European countries' responses to the immigration of displaced civilian men, women, and children of Iraq, Syria, Afghanistan, and a number of African countries; Islamophobia in Western countries fueled by fundamentalist Muslim terrorists; the ethnic cleansing in Myanmar (Burma) of Rohingyas; the forceful appropriation of white-owned farms in Zimbabwe; ethnic profiling by security forces including at points of entry into countries; the treatment of Palestinians by the Israeli state; rising anti-Semitism; the suppression of Ugihurs and Tibetans by China; and the continuing marginalization of first nation peoples and interethnic conflict in many postcolonial states.

This chapter examines some selected trends in intergroup relations and racism in the contemporary era.

\section{The Notion of Race}

The idea of race and especially its use in pseudoscientific disciplines such as eugenics is relatively recent in terms of human history. It denotes the classification of human beings or Homo sapiens in terms of patterns of physical appearances beginning with skin color (pigmentation), facial features, hair texture, physical size, and head shape. Patterns of these phenotypical features spread over geographical space and reflect both periodic isolation and intermixing among human populations. Biologists accept that all human beings belong to the one species of Homo sapiens and physical differences have arisen out of environmental conditions and over time, reproduction in relatively isolated gene pools. They have also maintained that biologically "race" is a meaningless notion as irrespective of phenotype and genotype human beings can and do interbreed to produce virile offspring. However, "race" is a social construct of dominant groups to identify themselves and other people who vary in physical appearances and may or may not have cultural differences. Over time, there has been a wide acceptance of racial categorization 
globally, regionally, and nationally. These categorizations include social and cultural attributes, self-identification, political-state based identification, and institutional definitions and practices (Banton 1967; Cohen 1999; Cox 1948; Rex 1983; Sivanandan 1982; Yeboah 1988).

The UNESCO Declaration on Race and Racial Prejudice (1978) has unequivocally declared that "all human beings belong to a single species and are descended from a common stock." However, "Legal and political language use the term races in the plural sense in order to cover different ethnicities or geographically characterizable subgroups, such as Caucasians, Africans, Mongoloids. Because of the well-established (but erroneous) custom, political and legal language is still using this term." (Gayle 2018).

There is some overlap between the concept of race and ethnic group. According to Stavenhagen:

...ethnic groups are historically given collectivities which have both objective and subjective characteristics, that is, their members acknowledge sharing common traits such as language, culture or religion, as well as a sense of belonging...Ethnic boundaries are socially constructed and may be more or less permeable....Ethnic group identity is the result of internal factors (common lifestyles, share beliefs), but also the outcome of relations the group entertains with other distinct but similarly constituted groups and with the state in any given country $(1996,4)$.

Historically, at the very beginnings of the categorization of human beings into races, intellectual, behavioral, and normative - therefore cultural - dimensions were included in the definition of race.

In the mid-eighteenth century, Carl Linnaeus, the renowned Swedish zoological taxonomist, classified human beings in the order of primates and belonging to the single species of Homo sapiens and several major subspecies. By the time of his writing, the European world had expanded to most parts of the world and knowledge about peoples in these places was shared among European scholars. His fourfold categorization included Americanus, Asiaticus, Africanus, and Europeanus. He proceeded to imbue these supposed subspecies with traits derived from Eurocentric perceptions. Europeanus were white, and supposedly gentle and inventive. Asiaticus were melancholic and greedy. Americanus were red, ill-tempered, and subjugated. Africanus were black, lazy, and impassive. " ... Linnaeus correlated skin color with medical temperament-Americans turned out to be 'choleric,' Europeans 'sanguine,' Asians 'melancholic,' and Africans 'phlegmatic' - moral characteristics, preferred clothing, and form of government" (Muller-Willie 2015, 597). The association of human anatomical features with intellect and other nonbiological attributes has been a feature of subsequent classification of varieties of human beings (Fredrickson 2002, 56). Linnaeus and, following him, Blumenbach, accepted that these varieties of human beings belonged to the one species (Ibid., 57). 


\section{Racialization: An Overview}

This categorization of vastly culturally diverse groups of people both in physical appearance and in terms of their cultures became an integral dimension of both identifying these groups in rather simplified categories, ascribing certain immutable attributes, and discriminating against them. European exploration and colonialism was accompanied by this process of naming and ascribing. In a number of cases, the names have stuck, even when they were blatantly in accurate from the start. Two examples should suffice. The term "Indian" was applied to the huge number of nations and ethnicities in the Americas and the Caribbean region. The Pacific island countries were divided into three regions based on the early explorers designation of them as Melanesian (black islands), Polynesian (many islands but inhabited by lighter skinned people), and Micronesian (very small islands, inhabited by brown skinned people). As pointed out by William Alkire, there is no clear demarcation between these islands, and indeed because of considerable intermixing in the one village, "The range of physical types found in most Oceanic communities is great, and it is fairly simple in Micronesia to find within the same village individuals whom anthropologists of 30 years ago would have labelled 'Mongoloid', Negroid; or Caucasoid"' (Alkire 1977, 9).

The role of dominant groups and states in defining "race" has been significant in the institution of discriminatory racist policies and practices. For examples, in the United States, one drop of black blood meant that the person was black irrespective of what the person looked like. This definition emerged in the southern states of the United States and was adopted at the national level (Davis, ND). Racial classification in Apartheid South Africa by the 1950 Population Registration Act stipulated three races: "white," "native" (black African), or "colored" (neither white nor "native"). Appearance and public perception were the two criteria for designating a person's race. Thompsell describes a simple racial test in South Africa thus:

\footnotetext{
Over the years, certain unofficial tests were also set up to determine the race of individuals who either appealed their classification or whose classification was challenged by others. The most infamous of these was the "pencil test", which said that if a pencil placed in one's hair fell out, he or she was white. If it fell out with shaking, 'colored', and if it stayed put, he or she was 'black'. Individuals could also be subjected to humiliating examinations of the color of their genitals, or any other body part that the determining official felt was a clear marker of race (Thompsell 2018).
}

Racialization has a long history and is associated with contact and interaction between people of different physical and cultural backgrounds. For instance, the expansion of the ancient Egyptian empire brought together Africans, Asians, and Europeans - in short, the inhabitants of two large continents: Africa and Eurasia. In AD 325, Alexander the Great led a military expedition across Asia Minor into the Indus valley conquering and subjugating various groups on the way. He was accompanied by a scholar, Megasthenes "who wrote the Indica, recording strange races of people in India: dog-headed men, men without mouths who got their nourishment from smelling fruits, men with their faces on their chests" (Palat 1998). This type of grossly distorted, exaggerated, and imaginary descriptions of 
non-European people became common place as European explorers and adventurers journeyed to Africa, Asia, the Americas, and the Pacific. These generally negative imageries and associated attributes were reproduced in caricatures of colored peoples in foreign lands.

Apart from conquest, trading was also a way of connecting groups. For instance, the Silk Road provided traders and travelers from the Far East, the Middle East, the near East, and parts of "civilized" Europe to establish networks and relationships across diverse regions and cultures (Gordon 2008). Presumably, in these relations, there would have been both positive and negative stereotyping that would have informed the trade partnerships that were engendered.

Colonialism also played a central part in the racialization process. Early Portuguese and Spanish intrusion into Africa and the Americas in the sixteenth century, followed by other Europeans, namely, the Dutch, the British, the French, the Germans, Italians, Belgians, over the subsequent 300 years resulted in several negative outcomes for peoples of the non-European world. Colonial conquest, the subjugation and decimation of native peoples, expropriation of the land of first nation peoples, their enslavement, as well as the scramble and partition of Africa, and much of the rest of the world have been held as morally reprehensible by Adam Smith. He stated that European superiority of force "enabled to commit with impunity every sort of injustice in those remote countries" (Smith 1811, 459; see, Ince 2017). Terms such as primitive accumulation (Karl Marx) and booty capitalism (Max Weber) could be applied to this phase of human history. European expansionism for economic and geopolitical reasons was accompanied by ideas of racial superiority over colored and black people. Such ideas emerged even more powerfully from the rationalization of the slavery of non-Christian native peoples and especially Africans, and subsequently by pseudoscientific racism beginning with social Darwinism, and then in the early twentieth century by eugenics. Rudyard Kipling wrote of the "white man's burden" and although Christianity coexisted with the enslavement of indigenous peoples and Africans for the better of 400 years, it lived with the contradiction of human beings made in the image of god and the horrendous treatment of black people and people of color. In fact, a pope accepted African slaves as gift in the sixteenth century endorsing the kidnapping and enslavement of non-Christians of color.

It is noteworthy, that in the post-WWII world following the revelation of the horrors of the Holocaust, the ideology of racial purity and superiority waned (together with Eugenics as a "science"), and the United Nations stood strongly against all forms of racism. However, Howard Zinn, the American historian, has written that:

Fifteen years ago, when I was teaching at Boston University, I was asked by a Jewish group to give a talk on the Holocaust. I spoke that evening, but not about the Holocaust of World War II, the genocide of six million Jews. It was the mid-eighties, and the U.S. government was supporting death squads in Central America, so I spoke of the deaths of hundreds of thousands of peasants in Guatemala and El Salvador, victims of American policy. My point was that the memory of the Jewish Holocaust should not be circled by barbed wire, morally ghettoized, kept isolated from other atrocities in history. To remember what happened to the 
six million Jews, I said, served no important purpose unless it aroused indignation, anger, action against all atrocities, anywhere in the world" (Zinn 1999).

Numerous atrocities akin to the Holocaust have been committed against mostly people of color over the last five centuries. The genocide and apparent extinction of the indigenous people of Tasmania, with the death of Truganini in 1876 is one example of the atrocities committed against native peoples by white settlers during early periods of colonization (Alexander 2006).

In 2008, Stanford University researchers estimated that the Americas had 40-80 million native peoples when European explorers arrived in the late fifteenth century. Within a very short period of time, $90 \%$ of the native peoples died because of their lack of immunity to European diseases, such as small box, influenza and measles, or were killed by the invaders. The sudden demise of these indigenous inhabitants in such large numbers resulted in rapid reforestation of the Americas and the reduction in the amount of carbon dioxide in the atmosphere. This engendered the "little ice age" that Europe experienced from 1500 to 1750 (Yirka 2011). The British used "germ warfare" against native peoples by deliberating infecting them with small pox (Dixon 2005).

It has been pointed out that in Australia there are numerous statues and war memorials in large and small cities and towns but there is no such commemoration of the war of conquest over Aboriginal peoples. A campaign to exterminate indigenous communities settled in Australia for over 65,000 years took place between 1788 and 1872. It is estimated that over 500 massacres occurred mainly by white settlers of aborigines and 250 massacre sites have been identified by researchers (Wahlquist 2018) and were rarely investigated, and no one was prosecuted for their homicide. The deaths in custody of first nation people continued after the 1991 Royal Commission of Inquiry in Aboriginal Deaths in Custody (Allam et al. 2018).

As noted earlier, slavery and colonialism have been pivotal in the evolution and inculcation of racist attitudes and behaviors. These will be addressed in the following section.

\section{The Ideology of Racism}

Although it is now accepted by nearly all scholars of human populations and biology that Homo sapiens evolved in sub-Saharan Africa over 250,000 years ago and spread over the rest of the world in the following centuries mixing with other varieties of local human species, there have been the purveyors of multiple origins of the human species. The later have argued that Europeans (Caucasians) evolved separately from black, yellow, and brown people. Another line of argument by other pseudoscientists of race is that white people are at a higher stage of evolution than black and colored people, or that the latter are degenerated races (see discussion on Yeboah 1988, 55 and 64).

Beyond these types of racial thinking, the ideology of racism derived from five sources. The first has its origins in the prejudice and treatment of the European 
peasantry or serfs by those who lorded over them. Those who labored in the fields and did menial work were deemed to be inferior breeds of humanity whose station in life was to toil and serve those whose station in life placed them in upper echelons of society. They were regarded for many centuries by the aristocracy, clergy, and commercial classes with "contempt, derision and fear" (Davis 1991, 180). They were deemed to be intellectually inferior, of loose morals, and inclined to have great sexual appetite as seen by the relative number of offsprings they had (a la Malthus) (Caldwell 1998) https://ucmp.berkeley.edu/history/malthus.html. In the earliest period of European settlement of the New World, people from this category were taken as slaves and as indentured laborers.

Second, racism emerged in tandem with the kidnapping, transportation, and the sale of Africans into slavery in the Americas and West Indies. The Atlantic triangular trade began in the sixteenth century and reached its apex in the mid to late nineteenth century. Between 10 million and 15 million were sold into slavery. Much of African stagnated as the continent's able bodied and productive young people were abducted and enslaved (Rodney 1972). Some of the negative stereotypes associated with European serfs were extended to black people and new ones added. Africans were deemed to be an inferior species of human beings closer to apes and monkeys. They were intellectually inferior, indolent, driven by emotions, sexually inclined, dishonest, dependent, and lacked creativity. African man had large penises (Yeboah 1988, 64). (Shakespeare's Othelo alludes to some of these negative qualities of the Moor.) There was Biblical justification provided for the inferiority of serfs as there was for black slaves. For the latter, Noah's curse on Ham permeated to all his descendants who were blacks. Without examining empirical evidence of any kind, a number of prominent European philosophers like Voltaire, Rousseau, David Hume, Immanuel Kant, and Hegel emphatically considered Africans to be inferior. Some of these philosophers maintained that Africans had not built a civilization (Henry 2004; Camara 2005).

The so-called "Polynesian labor trade" involved primarily the kidnapping, shipping, and forced labor of Melanesians from the Solomon Islands, Vanuatu, and islands of Papua New Guinea, as well as Micronesians, namely Ikiribati people, to a number of countries in the Pacific. Prominent among these were Australia (Queensland and New South Wales), Fiji, New Caledonia, and Samoa. Peruvian slavers also descended on Tuvalu to abduct whole villages of their inhabitants to work in guano mines of Peru and Chile. The periodic discovery of skeletal remains of these victims of slavery in Queensland and New South Wales evoked anger among Pacific islanders but also showed to them the systematic discrimination practiced by white planters in these countries against them (Armbruster 2017).

Third, anti-Semitism also appears to have its origins in the Bible, both old and new. The distinction between "God's chosen people," the Jews and Gentiles provided a problematic basis for inclusion and exclusion. Moreover, with Christianity, prejudice, discrimination, and pogroms against Jews were rationalized on the basis that they were the killers of Christ. Negative stereotypes included Jews as misers, money lenders, cunning and crafty, and dishonest. As a distinct religious minority, Jews suffered systematic discrimination over the centuries including violent 
pogroms in and forced exiles from many parts of Europe. Not unusually this was associated with nationalism and the rise of the modern European states. The Holocaust in Nazi Germany saw the horrific genocide of 6 million Jews in gas chambers of holding concentration camps in Germany and in Poland.

Fourth, European imperialism and colonialism meant the conquest, suppression, and subjugation of people of color in the Americas, Africa, Asia, and the Pacific. Accompanying these historical events were the notions of Darwinian "natural selection" and "survival of the fittest" to which was added "manifest destiny" as thousands and millions of indigenous people perished with European incursion and invasion. The conquest and occupation of the regions of the Global South was taken as evidence of both European racial superiority and the "white man's burden" to civilize and Christianize the rest of the world. Rampant racism accompanied the wars of appropriation against first nation peoples and European settlement of the Americas, parts of Africa, and Australasia (Zinn 1999; Davidson and Scarr 1970). Nuclear colonialism in many ways reflected the little regard for the well-being and lives of Micronesians, Tahitians, and aboriginal Australians by the United States, France, and Britain (Winchester 2015; MacLellan).

The fifth source of racist thinking and ideology derives from language and particularly the English language (and extends to other European languages). Language was (and is) an extremely portent ground for the evolution of racist thinking and practice. Fundamentally, the color black is associated with the devil and evil, and just about everything else that is bad and unpleasant, "black death," black list, black market, black arts, black magic, black Friday, and black attire associated with mourning and death. By contrast, the color "white" is associated with purity and good things, even lies could be made light with the reference to "white lies."

Sixth, racial and ethnic stereotypes and prejudices are to be found in most countries, including postcolonial states where certain groups who may physically appear to be similar have a history of competition and conflict often manufactured by divide and rule policies of the former colonizing power and/or by local dominant groups. These stereotypes, prejudices, and competitive relationship have led to horrific violence with scores of thousands being killed for instance during the partition of British India, in the "Biafran war" in Nigeria, and in the genocide in Rwanda. They also have fueled the long-standing conflict in Northern Ireland, Sri Lanka, and Kashmir. Black and colored people have expressed their racism in recent times towards to immigrants in South Africa and India.

The active recruitment of labor to work in colonial plantations and mines and the encouragement of the immigrant laborers to settle in the colonies together with bringing together diverse nationalities, ethnicities, and "tribes" in colonial states created complex multiethnic societies including the so-called plural societies. In nearly all these states, there have been issues relating to interethnic relations and systemic discrimination against minorities. The discrimination can be based on language, religion, physical appearance, and ethnic identity more generally. 


\section{Racism in the Contemporary World}

Over the last 300 years, countries of the world have become increasingly diverse, although there have been counter trends as well. For instance, Argentina's African inhabitants have diminished quite markedly over the last century. "The demographic shift has been sharp. In 1800, on the eve of revolution with Spain, blacks made up more than a third of the country, 69,000 of a total population of 187,000, according to George Reid Andrews's 2004 book Afro-Latin America. In 2010, 150,000 identified themselves as Afro-Argentine, or a mere 0.365 percent of a population of 41 million people, according to the census, the first in the country's history that counted race" (Luongo 2014). Currently, it could be argued that virtually all the 193 member states of the United Nations are multiethnic. The diversities in nearly all states have been the outcome of population migration as well as the political incorporation of culturally diverse groups by emergent states (Castles 2000; Stavenhagen 1996). The United States is perhaps the most culturally diverse country in the world with nationalities and ethnic groups from numerous parts of the planet. Even the most apparently homogenous countries of the world such as Japan and Samoa have minorities.

Racism based on discriminatory treatment by dominant groups is as widespread as the ubiquity of multiethnic societies. The concept has cognitive and behavioral dimensions. Stereotypes both negative (prejudice) and positive exist in ethnic (and racial groups). These originate in socialization, and experience including through the exposure to mass media with its portrayal of those who are different in appearance and who may have different cultures. Behavioral dimension of racism is usually associated with relative power and the capacity to discriminate against those of different ethnicity or "race." When such discrimination is systemic, the term institutionalized racism is used to distinguish it from inter-personal discrimination. A "culture of racism" exists in Britain and indeed in many countries of the world. As racial discrimination and racist behavior has at its core unequal power relations, such practices are found in wealthy countries that have drawn migrant laborers, and by those who comprise the dominant groups and classes in societies. In the notions of "old" and "new racism," distinction is drawn between the expression of open prejudice and discriminatory treatment of black people by whites of the period before the 1980s to more subtle forms in the last 30-40 years.

\section{"Old" and "New" Racism}

Basically, "old" racism denotes open forms of discrimination which in their extreme manifestation were seen in state-sponsored racism of Jim Crow, USA, and Apartheid South Africa. Prejudiced and racist behavior by whites were openly expressed, condoned, and even encouraged by law. With the Civil Rights Movement and the enactment of the Civil Rights Act (1964), open segregation, discrimination in education, employment, housing and in access to public utilities and services were proscribed in the United States. However, it is maintained that more subtle forms of 
racism continued and these are labelled "new racism." The opposition to affirmative action for Afro-Americans and other disadvantaged groups and the claims of "reverse racism" in a supposed social context of "equal opportunities" for all are perceived as new racism. The empirical evidence from countries where there has been a history of racism show that both institutionalized discrimination and interpersonal expression of prejudice continue to exist, and in some contexts thrive.

In the early twenty-first century nationalism, xenophobia and racism have been on the rise in Europe and the United States. These have been especially manifest in the response to the exodus of refugees and asylum seekers who traveled, including on foot to European country borders during the wars in Syria and Afghanistan, and the campaign for Brexit and its aftermath (Gayle 2018). But all European countries and especially those states that have been former colonial powers have deeply ingrained "cultures of racism" which is manifested at institutional and individual racist practices. This is reinforced by extreme right, neo-Nazi groups, and nationalistic political parties. As noted by other scholars, racism becomes amplified during times of economic crisis and wanes when the economic performance of European states is on the rise. Globalization, demographic changes, and the arrival of refugees and asylum seekers have given rise to a siege mentality among Europeans in a number of countries including Britain, France, Denmark, and Germany.

Institutionalized racism has been evident over and over again by the slowness of police in investigating and prosecuting perpetrators of hate crimes and violence against minority black and colored communities, and by police practice that has disproportionately targeted these communities. Police in Europe and the United States have a proclivity to stop, question, and search a disproportionate number of black persons. Criminal justice systems have been largely used to penalize individuals and groups from minority communities. A combination of institutional and individual racism has undermined minority access to education, employment, health, housing, and welfare. The "race riots" of the 1970s and 1980s, and in 2001 in the cities of United Kingdom, and subsequently in other European cities bought to the fore issues relating to how dominant communities, local governments, and central state institutions had been discriminating against minorities.

\section{Race Relations and Anti-racist Struggles}

With the rise of tensions and overt conflicts exemplified by demonstrations, riots, and response to police brutality and white racism in the United Kingdom, policies to dialogue and co-opt black community organizations and leaders become widespread. Although some scholars pointed out that the issue of racism and exclusion of minorities lay with the dominant group, and this is what has given rise to the "race problem," a number of local and national level initiatives led to the growth of race relations bodies. Some of these entities have been well funded and have been involved in promoting dialogue, reconciliation, mediation, and tolerance between whites and blacks. However, both institutionalized and interpersonal racism is deeply entrenched and racism continues in the United Kingdom (Sivanandan 1991). 
Opposition to racism has been undertaken by both those who have been its victims as well as those who opposed social injustices committed on racial grounds. The decimation of indigenous peoples the world over was opposed by individual Europeans, some were clergy men. Slave uprisings were common in the Caribbean region and there were white individuals who opposed slavery. In the nineteenth century, the abolition of slavery movement gained traction with the changing demands of capitalist enterprises. Slavery came to an end in the British Empire in the 1830s, and the American Civil War ended slavery in the United States in 1865. The French ended slavery in their colonies in late 1840s and Brazil did so in 1888 . Other forms of forced labor were to follow as for example the Indian Indenture Labour System (Tinker 1974).

However, racial equality was severely undermined during the late nineteenth century and well into the 1960s by Jim Grow laws in the southern states of the United States, colonialism in the Global South, the emergence of Apartheid in South Africa, and the color bar against the Windrush generation and their Asian counterparts in Britain. Responding to Enoch Powell's racist anti-immigration campaigns the British government enacted its first immigration legislation beginning in the 1960s which was eventually followed by the Immigration Act of 1971 and the Nationality Act of 1981. These sought both to encouraged black people to return to their countries of origins but also to restrict possibilities of long-term migration to Britain. Australia put in place a white Australia policy following its federation in 1901. Anti-racist struggles have been underway in North America, Europe, and South Africa for much of the twentieth and early twenty-first centuries. The American Civil Rights Movement led by Dr. Martin Luther King helped confront the openly racist system of segregation found in the southern states of the United States. The fight against racism continues in the post-Obama era with the "Black Lives Matter" movement in the United States. Far too many Afro-Americans, and especially young men are being killed by police in the United States.

The African National Congress with Nelson Mandela at its helm and their allies engaged in a peaceful campaign and an armed struggle to end Apartheid in South Africa. The internal struggle within South Africa was accompanied by a powerful international movement that finally led to the collapse of the racist regime. While racism persists in Britain and other European states, people of color and progressive white people have continued their struggle against institutional and interpersonal racism. Increasingly, this struggle has extended to campaigns against Islamophobia, as well as against the reemergence of anti-Semitism.

\section{Conclusion}

Racism is a socially constructed discourse and practice that has emerged over time and space. It is historically linked to anti-Semitism, slavery, colonialism, and contemporary national immigration policies of countries of the Global North. In fact, one could argue that the international division of labor itself reflects the long history of racism at the global level. The rise of right wing white neo-Nazi 
organizations and the apparent willingness of individuals with extremists believes to engage in extreme violence armed with semiautomatic weapons as well as using motor vehicles to run over people are contemporary phenomenon.

Racism is not limited to white people only as negative stereotyping but prejudice and discrimination are also found among people of color. The treatment of Dalits, Muslims, and other minorities in India remains a matter of concern for human rights defenders. The Chinese state has suppressed minorities such as Tibetans and Uighurs. Discrimination and interethnic tensions and conflict are to be found in most postcolonial states in Africa, Asia, South and Central America, the Caribbean, and the Pacific. Anti-Chinese riots have occurred in Tonga and the Solomon Islands, and Fiji has experienced political turmoil and four military coups that have featured indigenous Fijians and Indo-Fijians.

Clearly the wide prevalence and ubiquity of racism and the struggles to counter it means that no single paper or book can provide in-depth coverage of its many features, manifestations, and consequences.

\section{References}

Alexander A (2006) Truganini, Centre for Tasmanian Historical Studies. http://www.utas.edu.au/ library/companion_to_tasmanian_history/T/Truganini.htm

Alkire WH (1977) An introduction to the peoples and customs of Micronesia, 2nd edn. Cummings Publishing, Menlo Park

Allam L Wahlquist C, Banister J, Herbert M (2018) Indigenous Australian Deaths in Custody. https://www.theguardian.com/australia-news/ng-interactive/2018/aug/28/deaths-inside-indige nous-australian-deaths-in-custody

Armbruster S (2017) Islander graves rediscovered on 150th anniversary of 'sugar slave' trade. https://www.sbs.com.au/news/islander-graves-rediscovered-on-150th-anniversary-of-sugarslave-trade

Banton M (1967) Race relations. Basic Books, New York

Caldwell JC (1998) Malthus and the less developed world: the pivotal role of India. Popul Dev Rev 24(4):675-696. See also https://ucmp.berkeley.edu/history/malthus.html

Camara B (2005) The falsity of Hegel's theses on Africa. J Black Stud 36(1):82-96

Castles S (2000) Ethnicity and globalisation. Sage Books, London

Cohen P (1999) New ethnicities, old racism. Zed Books, London

Cox OC (1948) Class, caste and race. Doubleday, New York

Davidson JW, Scarr D (1970) Pacific Island portraits. In: Canberra: Australian National University press

Davis FJ (1991) Who is black? One nation's definition. https:/www.pbs.org/wgbh/pages/frontline/ shows/jefferson/mixed/onedrop.html

Dixon D (2005) Never come to peace again: Pontiacs uprising and the fate of the British empire in North America. University of Oklahoma Press, Oklahoma

Fredrickson GM (2002) Racism a short history. Scribe Publications, Melbourne

Gordon S (2008) When Asia was the world. Da Capo Press, Philadephia

Gayle D (2018) UK has seen 'Brexit-related' growth in racism, says UN representative. https:// www.theguardian.com/politics/2018/may/11/uk-has-seen-brexit-related-growth-in-racism-says-unrepresentative

Henry P (2004) Between Hume and Cugoano: race, ethnicity and philosophical entrapment. J Specul Philos, New Series 18(2):129-148. Identity and Ethnicity (2004) 
Ince OU (2017) Adam Smith, settler colonialism and cosmopolitan overstretch. Singapore Management University, Singapore. https://ink.library.smu.edu.sg/cgi/viewcontent.cgi?arti cle $=1017 \&$ context $=$ soss_research_all

Luongo MT (2014) Argentina rediscovers its African roots, New York Times (12 September), http://www.mixedracestudies.org/?tag=afro-argentines

Muller-Willie, S (2014/2015) Race and history: comments from an epistemological point of view. Sci Technol Human Values 39(4):597-606. https://doi.org/10.1177/0162243913517759

Palat RA 1998 'Warne, Waugh and Western Hypocrisy'. New Zealand Herald (16 December)

Rex J (1983) Race relations in sociological theory. Routledge and Kegan Paul, London

Rodney W (1972) How Europe underdeveloped Africa. Bogle-L'Ouverture Publications, London

Sivanandan A $(1982,1991)$ A different hunger. London: Pluto Press

Smith A (1811) The works of Adam Smith, LL.D., vol 3. London/Edinbugh. https://books.google. com.fj/books?id=DFpZAAAAcAAJ\&pg $=$ PA459\&lpg $=$ PA459\&dq $=$ adam + smith,+ enabled $+\mathrm{t}$ $\mathrm{o}+$ commit + every + sort + of + injustice + in + those + remote + countries $\%$ E $2 \% 80 \% 9 \mathrm{D} \&$ source $=$ bl\&o ts $=3$ Fm8R3sEOB\&sig $=$ ACfU3U0e9- 6 FwYEnmRHapTqU2HMLM59FA\&hl $=$ en\&sa $=X \&$ ved $=2$ ahUKEwiyxpTvqabhAhXRWisK $H$ HIqA04Q6AEwA3oECAcQAQ\#v $=$ onepage $\& q=a d$ am $\% 20$ smith $\% 2$ C $\% 20$ enabled $\% 20$ to $\% 20$ commit $\% 20$ every $\% 20$ sort $\% 20$ of $\% 20$ injustice $\% 20$ in $\% 20$ those $\% 20$ remote $\% 20$ countries $\%$ E2\%80\%9D\&f=false

Stavenhagen R (1996) Ethnic conflicts and the nation state. Macmillan Press, London

Thompsell A (2018) In the Apartheid state of South Africa (1949-1994), your racial classification was everything. https:/www.thoughtco.com/racial-classification-under-apartheid-43430

Tinker H (1974) A New System of Slavery The Export of Indain Labour Overseas, 1830-1920, Hansib Publications, London

Wahlquist C (2018) Evidence of 250 massacres of indigenous Australian mapped. https://www. theguardian.com/australia-news/2018/jul/27/evidence-of-250-massacres-of-indigenous-australi ans-mapped

Winchester S (2015) Pacific: the ocean of the future. William Collins, London

Yeboah SK (1988) The ideology of racism. Hansib Publishing Limited, London

Yirka B (2011) Research team suggests European Little Ice Age came about due to reforestation in New World. https://phys.org/news/2011-10-team-european-ice-age-due.html

Zinn H (1999) Respecting the Holocaust. Third World Traveler. http://www.thirdworldtraveler.com/ Zinn/RespectingHolocaust.html 